$\begin{array}{ll}\text { Nama } & \text { : Nicole Doelitzsch Liang } \\ \text { Nrp } & : 130219070 \\ \text { KP } & : \text { B }\end{array}$

Tugas Perekonomian Indonesia

(Tayibnapis, Wuryaningsih, \& Gora, 2021)

\title{
The Recovery of MSMEs and Efforts to Digitize
}

\begin{abstract}
Companies that are disrupting new media technology, especially during this Covid 19 era must have a new business platform. However, there are many incumbent companies that are less able to keep up. This study used a qualitative method, a case study approach. The analysis focuses on efforts to raise Medium, Small and Medium Enterprises (MSMEs) that contribute to improving the Indonesian economy. The findings show that their position in small and medium enterprises doesn't get strengthen by credit, training and mentoring programs. But to accelerate income distribution in Indonesia, They are still working to increase the literacy index and financial inclusion.
\end{abstract}

The Covid-19 pandemic has eroded people's income and purchasing power. Their savings are decreasing for consumption needs, especially those that experienced employment termination or laid off. We don't really know when is the Covid-19 pandemic will end, so there is a tendency for people to save rather than spend, and also return to their basic needs rather than tertiary needs, so that the sectors and subsectors producing basic needs will recover earlier. Small and medium enterprises are increasingly squeezed by the situation. The results of a survey conducted by the Central Bureau of Statistics of the Republic of Indonesia (September 2020) explained that there was a decrease in the income of micro and small businesses by $84 \%$ and $82 \%$ in medium and large businesses. During this pandemic, many MSMEs permanently closed and reduced workers. With a contribution of $61.1 \%$ to Gross Domestic Product, the recovery of the ultra-micro and MSME sectors is very urgent amidst the pressure of the Covid19 pandemic. The recovery of MSMEs cannot be separated from information technology, considering that digitalization is the key so that entrepreneurs can survive. Unfortunately, the process cannot take place immediately. It is best to join electronic trade organizers. Efforts to digitize MSMEs need to be maintained in various ways, including consistent and routine mentoring.

This research belongs to the qualitative category research with the aim to find out the development of MSMEs in Indonesia after being affected by the pandemic, a decrease in people's purchasing power and an economic recession. This qualitative research is a research strategy that involves empirical investigation of certain contemporary phenomena in real-life contexts using various data collection methods [6] and relies on triangulation of data generated from 3 methods, namely interviews, participant observation, and review notes during the interview. This qualitative descriptive study seeks to dismantle the existing conditions of MSMEs after a pandemic and economic recession which is associated with the development of 
digital technology and financial technology which is increasingly intertwined to the economy of micro businesses

Based on the current developing conditions, the government should focus more on controlling the Covid-19 pandemic so that confirmed cases can decrease and give confidence to the public, especially the middle and upper class, to shop again and restore consumption, given that Indonesia's economic growth is still supported by household consumption expenditures. The government has also prepared various scenarios to save small and ultramicro business affected by Covid-19, including formulating MSME protection and rescue schemes, ranging from social assistance, tax incentives, relaxation and credit restructuring, to expanding financing. One of the government's priorities must be Empowerment and comprehensive support for small businesses when carrying out transformation by restructuring the national economy in an effort to boost economic growth, prevent the recession and crisis of the Covid-19 pandemic, and significantly reduce unemployment and poverty. The use of digital financial services has the opportunity to drive the internet economy and is expected to support the financing of the productive sector. However, the biggest problem of financing the productive sector is the low productivity of ultra-micro-scale businesses. Moreover, the use of the internet can help ultramicro and micro businesses to play a bigger role as suppliers in the domestic supply chain so as to reduce the entry of imported goods. There should be planned social engineering to change the working behavior patterns of MSMEs towards working online, especially in order to compete with MSMEs from other countries. Local governments that have many MSMEs are trying to provide aid, credit, etc and stimulus funds to help arrange halal certificates and permits for MSME home industry products in an effort to encourage MSMEs to survive in the midst of the Covid-19 pandemic. In the future, stalls and MSMEs will become part of the e-commerce ecosystem and the mainstay of sales for fast moving consumer goods (FMCG) producers. So far the number of business is relatively small, This means that solutions and innovation are urgently needed for digitizing MSMEs. The problems faced by MSMEs is that there are still many micro small and medium entrepreneurs who are actually feasible, but not bankable. One of the efforts to overcome this problem is through business partnerships. If handled properly and maximally, MSMEs in Indonesia have the opportunity to contribute to a Gross Domestic Product of USD 140 billion or around IDR 2.052 trillion in 2030.

Digitalization has proven to be able to open up inclusivity and electronification in Indonesia. Digitalization and electronification of services can actually support economic recovery programs, such as the distribution of social assistance and financing for MSMEs. MSMEs need to be continuously encouraged so that they can be integrated into the national production system or global supply chain. MSMEs must be able to work on local advantages to produce special products so that they can be more competitive in both the domestic market and the international market. Thus, MSMEs need to develop these unprocessed products into special products to fill the global market, considering that MSME products have uniqueness and its own selling value compared to mass manufactured.

\section{Bibliography}

Tayibnapis, A. Z., Wuryaningsih, L. E., \& Gora, R. (2021, March 16). Medium, Small and Medium Enterprises and Digital Platforms. South Asian Journal of Social Studies and Economics, 10-19. DOI: 10.9734/SAJSSE/2021/v10i230258 
